\title{
Evaluation of temperate quality protein maize (QPM) hybrids for field performance and grain quality
}

\author{
Dragana Ignjatovic-Micic ${ }^{1 *}$, Marija Kostadinovic ${ }^{1}$, Sofija Bozinovic ${ }^{1}$, Olivera Djordjevic-Melnik ${ }^{1}$, \\ Goran Stankovic ${ }^{1}$, Nenad Delic ${ }^{1}$, and Jelena Vancetovic ${ }^{1}$
}

'Maize Research Institute, S. Bajica 1, 11000 Belgrade, Serbia. "Corresponding author (idragana@mrizp.rs).

Received: 20 May 2020; Accepted: 28 July 2020; doi:10.4067/S0718-58392020000400598

\begin{abstract}
Quality protein maize (QPM) (Zea mays L.) is primarily used for food in countries of tropical and sub-tropical regions where maize is the main source of protein. Although its cultivation in temperate regions is hampered by residues of exotic germplasm, it could be beneficial for use in livestock feeds as it was shown that substitution of standard maize with QPM can improve livestock characteristics and decrease dietary lysine supplementation. The aim of this study was to test 11 QPM hybrids obtained by crossing adapted QPM inbred lines for their performance in field trials in 2 $\mathrm{yr}$ at four locations, as well as to determine their relevant biochemical components. The main reason for rejecting nine QPM hybrids was low grain yield, standard hybrids had higher yields on average for 37.8\%. Hybrid ZPQPM6 had good agronomic characteristics, but its biochemical components were nonsignificantly different from the standard hybrid. Only hybrid ZPQPM13 met necessary criteria, grain yield comparable with standard hybrids, high tryptophan content in different environments (average $0.083 \%$ ) and hard endosperm (average score 1.87). Lysine content, measured after mercantile production, was $0.44 \%$. Quality index, although below the QPM threshold (which is $0.80 \%$ ) was significantly higher $(\mathrm{p}<0.05)$ in ZPQPM13 in comparison with standard hybrid, indicating improved nutritional quality of the protein. The results indicated that presence of exotic germplasm in these QPM hybrids is a consequential difficulty and that in their parental inbred lines at least one more backcross with temperate germplasm should be done to select better adapted QPM.
\end{abstract}

Key words: Adapted QPM, grain yield, kernel modifications, protein content, tryptophan content, Zea mays.

\section{INTRODUCTION}

Maize (Zea mays L.), like all cereals, has low nutritional quality due to poor content of essential amino acids lysine and tryptophan in the dominant seed storage protein fraction, zeins. The breakthrough in protein quality was achieved when Mertz et al. (1964) discovered natural occurring recessive opaque2 (o2) mutation, which reduces zein content and increases lysine content. However, due to the pleiotropic effects of $o 2$ gene, mutant kernels were with soft endosperm, increased susceptibility to pathogens and low yields. By using conventional breeding methods, $o 2$ maize was converted to quality protein maize (QPM) varieties with hard endosperm and high lysine content (Vivek et al., 2008). Lysine content of QPM can be $60 \%$ to $100 \%$ higher than the content of standard maize.

QPM is primarily used as food in undeveloped countries of tropical and sub-tropical regions, where maize is staple food and frequently the only source of proteins, because nutritional quality of the protein in QPM grain is similar to that of the protein from cow's milk (Krishna Motukuri, 2019). Besides its importance as food, QPM can be used as a component of livestock feed, especially in developed countries where $78 \%$ of total maize production is used for feed 
(Sofi et al., 2009). Monogastric animals (pigs, poultry, fish), like humans, cannot synthesize lysine and tryptophan de novo and thus these amino acids must be supplied through diets. It has been shown that substituting normal maize with QPM in feed diets could be profitable due to improved weight gain, feed conversion ratio and decreasing of dietary lysine supplementation (Mpofu et al., 2012; Agrawal et al., 2018; Thapa et al., 2020).

As QPM is of tropical and sub-tropical origin developed primarily for human consumption, information about its adaptation to temperate regions is scarce (Zarkadas et al.,2000; Ignjatovic-Micic et al., 2013; Worral al., 2015; Kostadinovic et al., 2016). Most of the work was dedicated to developing well adapted QPM inbred lines and promising results were reported. However, information on adapted QPM hybrid performance and its stability in different environments has not been presented. Ignjatovic-Micic et al. (2013) performed an experiment on 72 hybrids, obtained by crossing 27 adapted QPM lines (created at Iowa State University) with three standard elite lines, but only in $1 \mathrm{yr}$ and at one location. The results identified five hybrids with high tryptophan content and grain yield at the level of standard hybrids. The aim of the work presented herein was to test QPM hybrids obtained by crossing exclusively adapted QPM inbred lines for their performance in field trials in $2 \mathrm{yr}$ at four locations. Besides agronomic traits, protein and tryptophan contents were also measured and quality index (QI) and endosperm modifications were determined. Finally, as these hybrids are aimed for feed industry, relevant biochemical analyses were performed on mercantile grain of the best performing QPM hybrid.

\section{MATERIALS AND METHODS}

\section{Plant material}

Eleven quality protein maize (QPM) (Zea mays L.) hybrids were evaluated for agronomic traits in field trials. Parental lines included three QPM lines adapted to the US Corn Belt (Worral et al., 2015), obtained by the courtesy of M.P. Scott BQPM9, BQPM10 and BQPM11. Another four lines were developed at Maize Research Institute. Lines GS-4, GS-5 and GS-6 are of the same origin as American lines, but were selected in Zemun Polje, Serbia. Line ZPL5QPM is a commercial ZP line converted to its QPM version through marker assisted backcrossing (a total of two backcrosses with recurrent parent), using CIMMYT's CML144 line as a donor line (Kostadinovic et al., 2016). In winter nursery 2015/2016 (Chile), BQPM9, BQPM10, BQPM11, GS-4, GS-5 and GS-6 were crossed as female as well as male parents with converted ZPL5QPM line. Hybrid codes and formulas of the selected hybrids for field trials are as follows: ZPQPM1 (ZPL5QPM $\times$ BQPM9), ZPQPM2 (BQPM9 × ZPL5QPM), ZPQPM3 (BQPM10 × ZPL5QPM), ZPQPM4 (ZPL5QPM × BQPM10), ZPQPM5 (ZPL5QPM $\times$ BQPM11), ZPQPM6 (BQPM11 $\times$ ZPL5QPM), ZPQPM9 (GS-4 $\times$ ZPL5QPM), ZPQPM10 (ZPL5QPM $\times$ GS-4), ZPQPM11 (GS-5 × ZPL5QPM), ZPQPM13 (GS-6 $\times$ ZPL5QPM) and ZPQPM14 (ZPL5QPM $\times$ GS-6). Tryptophan content in parental lines ranged from 0.077\% (ZPL5QPM) to $0.097 \%$ (GS-6) and protein content from $11.05 \%$ (BQPM11) to $12.54 \%$ (GS-6).

\section{Field trials}

Field trials were conducted at four locations in 2017, according to the randomized complete block design (RCBD) with three replicates. Two locations where in the vicinity of Belgrade $\left(44^{\circ} 49^{\prime} \mathrm{N}, 20^{\circ} 28^{\prime} \mathrm{E}\right)$, one in Becej $\left(45^{\circ} 37^{\prime} \mathrm{N}, 20^{\circ} 02^{\prime} \mathrm{E}\right)$ and one in Subotica $\left(46^{\circ} 06^{\prime} \mathrm{N}, 19^{\circ} 39^{\prime} \mathrm{E}\right.$ ). Five standard hybrids (SH1-SH5 of FAO 500-600 maturity group, consisted of leading ZP hybrids) were used as controls. The elementary plot consisted of two rows $0.75 \mathrm{~m}$ apart with 20 hills per row $0.40 \mathrm{~m}$ from each other. Plant density was $66.667 \mathrm{plants} \mathrm{ha-1}^{-1}$. Standard agronomical practices were performed. Measured agronomic traits were plant height $(\mathrm{PH}, \mathrm{cm})$, ear height $(\mathrm{EH}, \mathrm{cm}), \mathrm{PH} / \mathrm{EH}$ ratio, number of leaves above the ear $(\mathrm{NL})$, stand (S, \%), lodged plants (LP, \%), cob percentage (Cob, \%), grain moisture at harvest (GM, \%), and grain yield (GY) adjusted to $14 \%$ grain moisture $\left(\mathrm{t} \mathrm{ha}^{-1}\right)$.

Based on the results, only hybrids ZPQPM6 and ZPQPM13 fulfilled GY and most of the other agronomic trait requirements, viz. they were at the level of the average of all standard hybrids. Field trials with these two hybrids were conducted in 2018, in the similar experiment as described above, but only one standard hybrid the same as in 2017 was used (ZP606). This is because only ZP606 standard is of FAO 700 group (the other standards are of FAO 500-600) and QPM hybrids proved to be of late maturity group (FAO 700-800) in 2017 field trials.

In 2019, a small scale experimental mercantile production of ZPQPM13 was performed in spatial isolation on 0.20 ha, simulating hybrid production conditions. Measured traits included GY, contents of macronutrients (proteins, starch and lipids), as well as contents of limiting amino acids in broiler diets. 


\section{Kernel modifications and biochemical analysis of hybrids}

For these analyses, hybrids were sown at two locations in two replicates according to RCBD in 2017 and 2018. To avoid xenia effect, selfing of hybrids was done (10 plants in each replicate). After harvesting, drying, and shelling, 300 kernels from each ear were taken and saved separately, representing samples for further analysis.

For each hybrid 400 kernels (40 kernels from 10 ears) were scored according to Vivek et al. (2008), where softness expresses itself as an opaque and hardness as a translucent phenotype. Kernel modifications were visually assessed using light table, according to the scoring scale from 1 (completely translucent, with no opaqueness) to 5 (completely opaque). Modification score 2 was given to the kernels which were 25\% opaque, while scores 3 and 4 were given to 50\% and $75 \%$ opaque kernels, respectively.

Each hybrid was represented by 60 randomly chosen kernels (six per ear), divided into two samples consisting of 30 kernels each. Kernels were dried in a controlled oven at $65^{\circ} \mathrm{C}$ overnight (16-18 h) and milled in a lab mill (Cyclotec 1093, FOSS Tecator, Hilleroed, Sweden). The flour was defatted by hexane treatment for $4 \mathrm{~h}$ in Soxhlet extractor (INKOLAB, Zagreb, Croatia).

Tryptophan content (TC) was determined using the colorimetric method explained in Twumasi-Afriyie et al. (2016). The colour was developed in the reaction of flour hydrolysate (obtained by overnight digestion with papain solution at $65{ }^{\circ} \mathrm{C}$ ) with glyoxylic acid and ferric chloride dissolved in sulfuric acid. After incubation at $65^{\circ} \mathrm{C}$ for $15 \mathrm{~min}$, absorbance was read at $560 \mathrm{~nm}$. Tryptophan content was calculated using a standard calibration curve, developed with known amounts of tryptophan, ranging from 0 to $30 \mu \mathrm{g} \mathrm{mL}^{-1}$.

The protein content (PC) was determined by the standard Kjeldahl method using $2200 \mathrm{Kjeltec}$ auto distillation unit (FOSS, Tecator, Sweden), based on $\mathrm{N}$ determination as explained in Vivek et al. (2008). The protein was estimated from the $\mathrm{N}$ value as: $\%$ protein $=\% \mathrm{~N} \times 6.25$ (conversion factor). Quality index $(\mathrm{QI})$, defined as tryptophan to protein ratio in the sample, was calculated as: $\mathrm{QI}=100 \times$ (tryptophan content in the sample/protein content in the sample).

\section{Biochemical analysis of mercantile ZPQPM13 hybrid}

Mercantile ZPQPM13 hybrid was analysed for protein, lipids, starch and, amino acids (tryptophan, lysine, threonine, methionine and cysteine) contents on 12 randomly selected samples (300 $\mathrm{g}$ were taken from top, middle and bottom of twelve $25 \mathrm{~kg}$ bags). Protein content was determined by Kjeldahl method and TC by the colorimetric method, as described above. Lipids, starch and amino acids were analyzed commercially by the accredited reference SP Laboratory, Becej, Serbia (http://www.splaboratorija.rs). Lipids were determined by a Weibull-Stoldt standard gravimetric method; starch was determined by a standard polarimetric method (ISO 6493:2000); and amino acids content by a modified standard method (ISO13903:2005), using ion exchange chromatography with electrochemical detector.

\section{Statistical analysis}

Statistical analysis was done according to ANOVA for a two factorial RCBD design for agronomic traits (genotypes and locations). Years were not included because majority of potential QPM hybrids did not achieve GY at the level of the average of all standard hybrids in 2017 and were excluded from field trials in 2018. On the other hand, three factorial RCBD design for biochemical traits (genotypes, years and locations) was performed. In this case, year was one of the factors because biochemical analyses were done only on the QPM hybrids with requested GY criteria. Fisher's LSD test at 0.05 probability level between hybrid means was obtained. These analyses were performed in MSTAT-C program (Plant and Soil Sciences, Michigan State University, East Lansing, Michigan, USA).

\section{RESULTS}

\section{Field trials}

ANOVA for the agronomic traits of QPM and standard hybrids in 2017 revealed significant differences between genotypes, as well as between locations, for all traits (data not shown). Difference between genotypes was at $\mathrm{p}<0.01$, except for LP $(\mathrm{p}<0.1)$. Similarly, significant difference between locations for all traits was at $\mathrm{p}<0.01$, except for stand $(\mathrm{p}<0.05)$. Replication was insignificant for all traits except PH. Genotype $\times$ Location interaction was insignificant for stand, LP, and Cob, significant at $\mathrm{p}<0.1$ for $\mathrm{EH} / \mathrm{PH}$ and for all the other traits at $\mathrm{p}<0.01$. 
Fisher's LSD showed significant differences between most QPM hybrids and standard hybrids for several traits, including PH, EH/PH, stand, Cob and GY (Table 1). Standard hybrids had higher yields on average for 37.8\%. The only three hybrids with GY at the level of two or three standard hybrids (out of five) were ZPQPM5, ZPQPM6 and ZPQPM13. ZPQPM5 was significantly different from standard hybrids for $\mathrm{EH}, \mathrm{EH} / \mathrm{PH}$, stand and Cob. The other two hybrids were significantly different from standard hybrids for one trait each - ZPQPM6 for Cob and ZPQPM13 for GM, which was the highest moisture content among all tested hybrids. Because ZPQPM6 and ZPQPM13 hybrids were, for GY and for seven out of eight other analysed traits, at the level of at least with one standard hybrid, they were chosen for further analyses.

ANOVA for agronomic traits of ZPQPM6, ZPQPM13 and standard hybrid ZP606 in 2018 revealed significant differences between genotypes and locations for all traits at $\mathrm{p}<0.01$, same as in 2017 (data not shown). However, replication was significant for most traits (except for Cob and GY), contrary to 2018. Genotype $\times$ Location interaction was the same as in 2018, except for NL (insignificant) and Cob (significant at $\mathrm{p}<0.01$ ).

Fisher's LSD (Table 2) showed significant differences between QPM hybrids and standard hybrid for PH, LP, GM and GY. Standard ZP606 hybrid had significantly lower PH, lower percentage of LP, lower GM and higher GY. Although significantly different from both QPM hybrids, Cob of ZP606 had the value in between the two hybrids. Considering the rest of the traits, ZP606 was significantly different from one of the two QPM hybrids.

Percentage of differences between the measured traits in 2017 and 2018 for the three hybrids are depicted in Figure 1. It can be noticed that all three genotypes had higher values for PH, EH, NL, PL, and GY, while for EH/PH, stand and Cob had lower values in 2018. In the same year, GM performed differently for each hybrid - it was higher for ZPQPM6, approximately the same in ZPQPM13 and lower in ZP606. Considering LP, it was approximately 3 and 6 times higher in 2018 for ZPQPM6 (3.41\% vs. 1.26\%) and ZPQPM13 (1.95\% vs. 0.31\%), respectively (data not presented in Figure 1). Apart from LP, it can be noted that the biggest changes occurred in GY, followed by PH.

Table 1. Fisher's LSD test for quality protein maize (QPM) and standard hybrids agronomic traits measured in 2017.

\begin{tabular}{|c|c|c|c|c|c|c|c|c|c|}
\hline Hybrid & $\mathrm{PH}$ & $\mathrm{EH}$ & $\mathrm{PH} / \mathrm{EH}$ & NL & Stand & LP & Cob & GM & GY \\
\hline & $\mathrm{cl}$ & 1 & $\%$ & & \multicolumn{4}{|c|}{$\%$} & $\mathrm{t} \mathrm{ha}^{-1}$ \\
\hline ZPQPM1 & $219.4 c-f$ & $80.88 \mathrm{gh}$ & $36.89 \mathrm{e}$ & $5.26 \mathrm{~h}$ & $58.13 \mathrm{~h}$ & $4.80 \mathrm{ab}$ & $22.91 \mathrm{~b}$ & $25.15 b c$ & $4.522 \mathrm{~h}$ \\
\hline ZPQPM2 & $235.5 \mathrm{ab}$ & $87.06 \mathrm{ef}$ & $37.03 \mathrm{de}$ & $5.70 \mathrm{~d}-\mathrm{g}$ & $91.88 \mathrm{def}$ & $3.08 \mathrm{abc}$ & $24.09 \mathrm{~b}$ & $26.88 \mathrm{a}$ & $6.145 \mathrm{def}$ \\
\hline ZPQPM3 & $223.1 \mathrm{~cd}$ & $82.64 \mathrm{~g}$ & $37.09 \mathrm{de}$ & $5.98 \mathrm{bc}$ & 94.38a-f & $0.32 \mathrm{c}$ & $22.39 b$ & $21.70 \mathrm{~g}$ & $5.722 \mathrm{fg}$ \\
\hline ZPQPM4 & $219.5 c-f$ & $77.53 \mathrm{~h}$ & $35.21 \mathrm{f}$ & $5.92 \mathrm{bcd}$ & $90.00 \mathrm{f}$ & $1.00 \mathrm{bc}$ & $23.51 \mathrm{~b}$ & $21.07 \mathrm{~g}$ & $5.065 \mathrm{gh}$ \\
\hline ZPQPM5 & $212.4 \mathrm{~g}$ & $81.00 \mathrm{gh}$ & $38.18 \mathrm{de}$ & $5.60 \mathrm{fg}$ & $90.63 \mathrm{ef}$ & $1.02 \mathrm{bc}$ & $23.34 \mathrm{~b}$ & $25.06 \mathrm{bc}$ & $7.156 \mathrm{c}$ \\
\hline ZPQPM6 & $217.4 \mathrm{~d}-\mathrm{g}$ & $87.50 \mathrm{ef}$ & $40.36 c$ & 5.63efg & $94.06 \mathrm{~b}-\mathrm{f}$ & $1.26 \mathrm{abc}$ & $23.01 \mathrm{~b}$ & $25.16 \mathrm{bc}$ & $7.030 \mathrm{~cd}$ \\
\hline ZPQPM9 & $223.6 \mathrm{c}$ & $101.80 \mathrm{a}$ & $45.59 \mathrm{a}$ & $5.76 c-f$ & $93.13 \mathrm{c}-\mathrm{f}$ & $4.77 a b$ & $26.86 \mathrm{a}$ & $27.29 \mathrm{a}$ & $5.349 \mathrm{fgh}$ \\
\hline ZPQPM10 & $213.6 \mathrm{fg}$ & $94.94 b c$ & $44.46 \mathrm{a}$ & $5.46 \mathrm{gh}$ & $82.81 \mathrm{~g}$ & $1.73 a b c$ & $23.86 \mathrm{~b}$ & $24.35 \mathrm{~cd}$ & $5.122 \mathrm{gh}$ \\
\hline ZPQPM11 & $218.5 \mathrm{c}-\mathrm{g}$ & 97.94ab & $44.83 \mathrm{a}$ & $5.45 \mathrm{gh}$ & $95.63 a-e$ & $5.02 \mathrm{a}$ & $23.09 \mathrm{~b}$ & $22.24 \mathrm{fg}$ & $5.958 \mathrm{efg}$ \\
\hline ZPQPM13 & $221.5 \mathrm{cde}$ & $91.88 \mathrm{~cd}$ & $41.52 \mathrm{bc}$ & $6.050 \mathrm{~b}$ & $96.88 \mathrm{a}-\mathrm{d}$ & $0.32 \mathrm{c}$ & $19.81 \mathrm{c}$ & 26.33ab & $7.702 b c$ \\
\hline ZPQPM14 & $218.3 \mathrm{c}-\mathrm{g}$ & $84.06 f g$ & $38.55 \mathrm{~d}$ & $5.97 \mathrm{bcd}$ & $90.31 \mathrm{ef}$ & $0.00 \mathrm{c}$ & $18.90 \mathrm{c}$ & $24.21 \mathrm{~cd}$ & $6.812 \mathrm{cde}$ \\
\hline ZP555 & $217.5 \mathrm{c}-\mathrm{g}$ & $90.50 \mathrm{de}$ & $41.65 b c$ & $5.76 c-f$ & $98.44 \mathrm{abc}$ & $0.00 \mathrm{c}$ & $18.11 \mathrm{c}$ & $22.49 \mathrm{efg}$ & $9.165 \mathrm{a}$ \\
\hline ZP560 & $238.5 \mathrm{a}$ & $97.56 \mathrm{~b}$ & $40.94 c$ & $6.14 b$ & $99.69 \mathrm{a}$ & $0.00 \mathrm{c}$ & $17.54 \mathrm{c}$ & $21.52 \mathrm{~g}$ & $7.679 b c$ \\
\hline ZP600 & $231.6 \mathrm{~b}$ & $94.69 \mathrm{bc}$ & $41.00 \mathrm{c}$ & $6.47 \mathrm{a}$ & 98.81ab & $3.12 \mathrm{abc}$ & $18.26 \mathrm{c}$ & $22.35 f g$ & $8.805 \mathrm{a}$ \\
\hline ZP666 & $221.0 \mathrm{cde}$ & 89.94de & $40.79 \mathrm{c}$ & $5.91 \mathrm{~b}-\mathrm{e}$ & 98.44abc & $0.00 \mathrm{c}$ & $17.99 \mathrm{c}$ & 23.39def & 8.616ab \\
\hline ZP606 & 215.9efg & $91.94 \mathrm{~cd}$ & $42.72 b$ & $6.16 \mathrm{~b}$ & $98.75 \mathrm{ab}$ & $0.00 \mathrm{c}$ & $19.02 \mathrm{c}$ & $24.01 \mathrm{cde}$ & $7.452 \mathrm{c}$ \\
\hline $\mathrm{LSD}_{0.05}$ & 6.09 & 4.09 & 1.54 & 0.28 & 5.46 & 3.87 & 2.34 & 2.418 & 0.998 \\
\hline
\end{tabular}

PH: Plant height; EH: ear height; NL: number of leaves above the ear; LP: lodged plants; GM: grain moisture; GY: grain yield.

All different letters in the column designate significant differences at 0.05 probability level.

Table 2. Fisher's LSD test for quality protein maize (QPM) and standard hybrids agronomic traits measured in 2018.

\begin{tabular}{|c|c|c|c|c|c|c|c|c|c|}
\hline Hybrid & $\mathrm{PH}$ & EH & $\mathrm{PH} / \mathrm{EH}$ & NL & Stand & LP & $\mathrm{Cob}$ & GM & GY \\
\hline & & . & $\%$ & & \multicolumn{4}{|c|}{$\%$} & $\mathrm{tha}^{-1}$ \\
\hline ZPQPM6 & $271.9 \mathrm{~b}$ & $96.05 \mathrm{a}$ & $35.29 \mathrm{a}$ & $5.95 b$ & $89.35 b$ & $3.41 \mathrm{a}$ & $20.60 \mathrm{a}$ & $26.85 \mathrm{a}$ & $10.02 \mathrm{~b}$ \\
\hline ZPQPM13 & $277.4 \mathrm{a}$ & $93.27 \mathrm{~b}$ & $33.57 \mathrm{~b}$ & $6.41 \mathrm{a}$ & $94.05 \mathrm{a}$ & $1.95 \mathrm{~b}$ & $17.09 \mathrm{c}$ & $26.01 \mathrm{~b}$ & $10.59 \mathrm{~b}$ \\
\hline ZP606 & $267.9 \mathrm{c}$ & $94.95 b$ & $35.36 \mathrm{a}$ & $6.50 \mathrm{a}$ & $93.39 \mathrm{ab}$ & $0.76 \mathrm{c}$ & $17.97 \mathrm{~b}$ & $22.87 \mathrm{c}$ & $12.55 \mathrm{a}$ \\
\hline $\operatorname{LSD}_{0.05}$ & 3.98 & 1.05 & 1.67 & 0.44 & 4.07 & 0.19 & 0.85 & 0.83 & 1.93 \\
\hline
\end{tabular}

PH: Plant height; EH: ear height; NL: number of leaves above the ear; LP: lodged plants; GM: grain moisture; GY: grain yield.

All different letters in the column designate significant differences at 0.05 probability level. 
Figure 1. Difference in percentages of measured agronomic traits between 2017 and 2018.

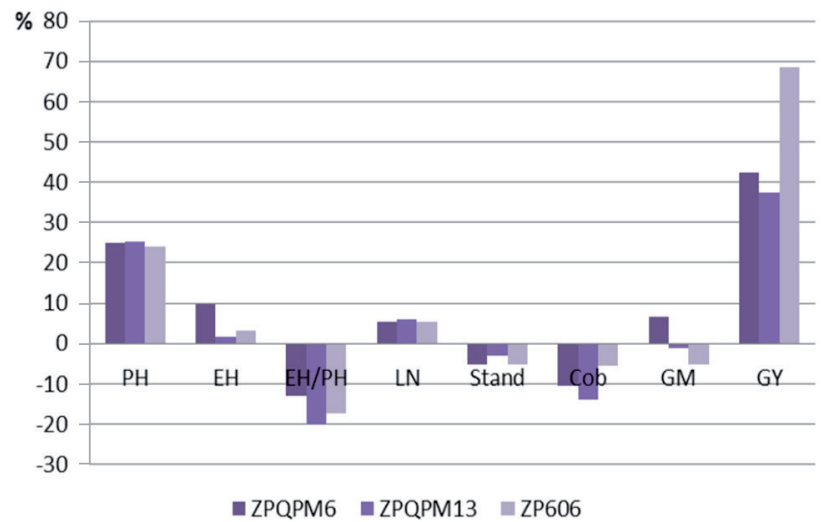

PH: plant height; EH: ear height; LN: number of leaves above the ear; GM: grain moisture; GY: grain yield.

\section{Kernel modifications and biochemical analysis of hybrids}

The results of scoring kernel types revealed over 90\% of good (types 1 and 2) and medium (type 3) endosperm modifications (Figure 2). In ZPQPM6 84.81\% of the kernels were of type 1 and 2, while in ZPQPM13 this percentage was $82.18 \%$. Percentage of poor (type 4) or no modifications (type 5) was 5.25\% for ZPQPM6 and $6.68 \%$ for ZPQPM13. Nonsignificant differences in endosperm modifications were found neither among years nor between the QPM hybrids.

The results of biochemical analysis of ZPQPM6, ZPQPM13 and ZP606 are given in Table 3. Overall, ZPQPM13 had the highest TC $(0.083 \%)$ and the highest QI $(0.70 \%)$, while the lowest TC $(0.070 \%)$ and the lowest QI $(0.60 \%)$ were found in the standard hybrid ZP606. Protein content was in the range from $11.23 \%-11.81 \%$. Considering years, TC and QI were higher in 2017 in QPM hybrids, while in ZP606 they were more uniform over the years. Protein content was higher in 2018 in all three hybrids. Percentage of differences in TC, PC and QI in 2017 and 2018 is illustrated in Figure 3.

ANOVA for biochemical traits revealed that year and hybrid were significant at $\mathrm{p}<0.001$ for TC, PC and QI (except hybrid for PC that was at $\mathrm{p}<0.01$; data not shown). Replication was insignificant for all three traits, while location was significant only for QI $(\mathrm{p}<0.01)$. Considering interactions, Year $\times$ Location was significant for TC $(\mathrm{p}<0.001)$ and PC $(\mathrm{p}<0.01)$, Year $\times$ Hybrid for TC $(\mathrm{p}<0.05)$ and $\mathrm{QI}(\mathrm{p}<0.001)$, Year $\times$ Location for QI $(\mathrm{p}<0.05)$, and Year $\times$ Location $\times$ Hybrid for TC and QI at $\mathrm{p}<0.05$.

Figure 2. Percentage of good (GM), medium (MM) and poor/no endosperm modifications (PM/NM) in quality protein maize (QPM) hybrids.

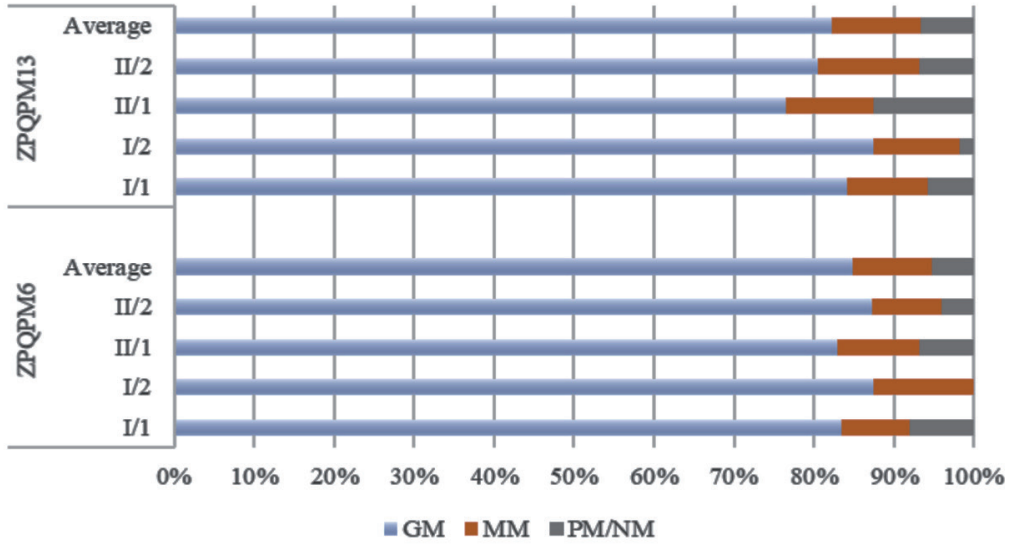

I/1: first year/first location; I/2: first year/second location; II/1: second year/first location; II/2: second year/second location.

GM: Kernel types 1 and 2; MM: kernel type 3; PM/NM: kernel types 4 and 5. 
Table 3. Tryptophan (TC) and protein content (PC) and quality index (QI) of the selected quality protein maize (QPM) and standard hybrids.

\begin{tabular}{lcccc}
\hline \multirow{2}{*}{ Genotype } & & \multicolumn{3}{c}{ Trait } \\
\cline { 3 - 5 } ZPQPM6 & Year/Location & TC & PC & QI \\
\cline { 3 - 4 } & & & $\%$ & \\
& I/1 & 0.087 & 11.20 & 0.78 \\
& I/2 & 0.075 & 10.52 & 0.71 \\
& Average I & 0.081 & 10.86 & 0.75 \\
& II/1 & 0.069 & 11.12 & 0.62 \\
& II/2 & 0.070 & 12.07 & 0.58 \\
& Average II & 0.070 & 11.60 & 0.60 \\
ZPQPM13 & Average I+II & 0.076 & 11.23 & 0.67 \\
& I/1 & 0.089 & 12.16 & 0.73 \\
& I/2 & 0.081 & 11.22 & 0.73 \\
& Average I & 0.085 & 11.69 & 0.73 \\
& II/1 & 0.077 & 11.22 & 0.69 \\
& II/2 & 0.082 & 12.64 & 0.65 \\
Average II & 0.080 & 11.93 & 0.67 \\
& Average I+II & 0.083 & 11.81 & 0.70 \\
& I/1 & 0.069 & 11.33 & 0.61 \\
& I/2 & 0.070 & 10.67 & 0.66 \\
& Average I & 0.070 & 11.00 & 0.64 \\
II/1 & 0.070 & 11.17 & 0.62 \\
& II/2 & 0.070 & 12.05 & 0.58 \\
& Average II & 0.070 & 11.62 & 0.60 \\
& Average I+II & 0.070 & 11.30 & 0.62
\end{tabular}

TC: Tryptophan content; PC: protein content; QI: quality index.

Figure 3. Difference in percentage of tryptophan content (TC), protein content (PC) and quality index (QI) between 2017 and 2018.

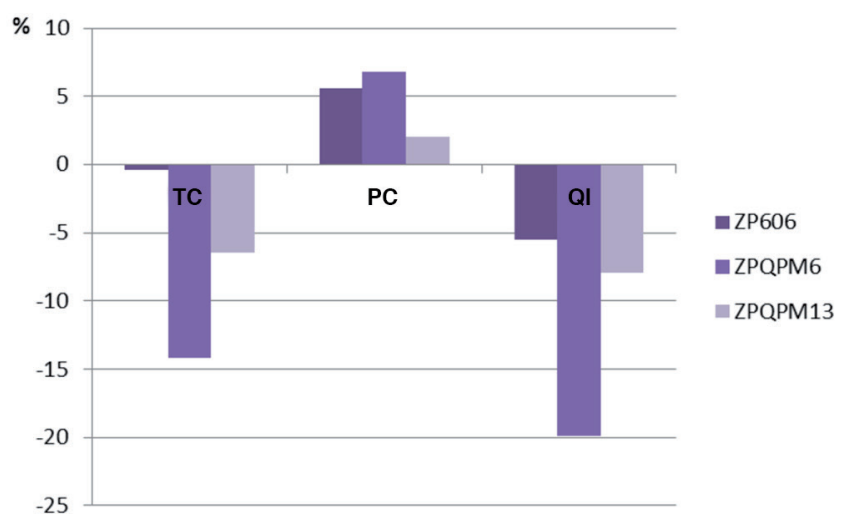

Fisher's $\mathrm{LSD}_{0.05}$ test (Table 4) showed significant differences between ZPQPM13 and ZP606 for all three traits. ZPQPM13 was also significantly different from ZPQPM6 for PC and QI. The only significant difference between ZPQPM6 and ZP606 was found for QI. Considering biochemical traits ZPQPM13 was the most favourable hybrid and was chosen for experimental mercantile production in 2019, to obtain seed for feeding trials with broilers. Female parent of this hybrid was selected in Serbian conditions, while female parent of ZPQPM6 was selected in the USA. This could be the reason of better performance of ZPQPM13 over ZPQPM6, although ZPQPM13 had higher GM, since both hybrids had a common father component. Also, as it was stated before, line GS-6, female parent of ZPQPM13, had the highest $\mathrm{TC}$ and $\mathrm{PC}$ of all parental lines in the research.

\section{GY and biochemical analysis of mercantile ZPQPM13 hybrid}

In mercantile production, ZPQPM13 hybrid yielded $7.5 \mathrm{t} \mathrm{ha}^{-1}$. Biochemical analysis (Table 5) revealed high lysine content of $0.44 \%$ and TC of $0.075 \%$ - much lower than in field trials $(0.083 \%)$. Protein content was also lower, $10.00 \%$ compared to $11.81 \%$, while QI was higher - $0.77 \%$ vs. $0.70 \%$. Contents (\%) of starch, lipids and several essential amino acids which are limiting in broiler diets are also presented. 
Table 4. Results of Fisher's LSD test for tryptophan content (TC), protein content (PC) and quality index (QI).

\begin{tabular}{|c|c|c|c|c|}
\hline \multicolumn{2}{|l|}{ Hybrid } & \multirow{2}{*}{$\begin{array}{r}\mathrm{TC} \\
\end{array}$} & \multirow{2}{*}{ PC } & \multirow{2}{*}{ QI } \\
\hline & & & & \\
\hline ZPQPM6 & Average & $0.075 \mathrm{ab}$ & $11.23 \mathrm{~b}$ & $0.67 \mathrm{~b}$ \\
\hline ZPQPM13 & Average & $0.083 \mathrm{a}$ & $11.81 \mathrm{a}$ & $0.70 \mathrm{a}$ \\
\hline ZP606 & Average & $0.070 \mathrm{~b}$ & $11.31 \mathrm{~b}$ & $0.62 \mathrm{c}$ \\
\hline $\mathrm{LSD}_{0.05}$ & & 0.011 & 0.313 & 0.011 \\
\hline
\end{tabular}

All different letters in the column designate significant differences at 0.05 probability level.

Table 5. Biochemical analysis of mercantile kernel of ZPQPM13 hybrid.

\begin{tabular}{lrrrr}
\hline Trait & Average & SD & Max & Min \\
\hline Macronutrients & & & & \\
Proteins, \% & 10.000 & 0.05 & 10.240 & 9.170 \\
Starch, \% & 60.870 & 0.92 & 62.440 & 59.220 \\
Lipids, \% & 4.930 & 0.35 & 5.860 & 4.540 \\
Essential amino acids & & & & \\
Lysine, \% & 0.440 & 0.03 & 0.480 & 0.400 \\
Tryptophan, \% & 0.077 & 0.01 & 0.078 & 0.075 \\
Threonine, \% & 0.390 & 0.03 & 0.440 & 0.350 \\
Methionine, \% & 0.120 & 0.01 & 0.130 & 0.100 \\
Cystine, \% & 0.090 & 0.01 & 0.110 & 0.080 \\
\hline
\end{tabular}

\section{DISCUSSION}

One of the most challenging downsides of QPM is achieving GY at the level of standard hybrids. Although some QPM cultivars are hard to distinguish from non-QPM, standard maize still yields more (Tandzi et al., 2017). This is in accordance with our experiment as only three out of 11 QPM hybrids analysed in this research had yields comparable to the standards in the first year of the experiment (2017). QPM germplasm originates from tropical and sub-tropical regions and low yields of QPM hybrids can be attributed to the presence of exotic germplasm, which leads to incomplete adaptation to temperate climate. For example, parental line ZPL5QPM is a commercial ZP line converted to its QPM version through marker assisted backcrossing, using CIMMYT's CML144 line as a donor line (Kostadinovic et al., 2016) and consequently contains $12.5 \%$ of donor germplasm.

In the second year of the experiment (2018), QPM hybrids ZPQPM6 and ZPQPM13, as well as the standard hybrid ZP606 (which was comparable with the QPM hybrids in 2017) were tested in field trials. The results showed higher PH, $\mathrm{EH} / \mathrm{PH}, \mathrm{NL}$ and GY in all three hybrids compared to 2017. This increase could have been expected, as summer in 2017 was the second hottest summer ever in Serbia, accompanied with extreme drought (HIDMET, 2017). On the contrary, summer in 2018 although hot was characterized with average to high rainfalls (HIDMET, 2019). It is well known that maize phenotypic expression is suppressed under water deficit stress, including plant height, number of leaves and seed weight (Nabizadeh et al., 2012; Sah et al., 2020). Drought stress during flowering period, depending on its severity, can significantly reduce GY. Mi et al. (2018) found GY reduction by $41.6 \%$ to $46.6 \%$, and Sah et al. (2020) by $38.48 \%$ to $55.95 \%$ under drought stress. In our experiment, GY under sufficient water supply was increased for approximately $40 \%$ for QPM hybrids and for nearly 70\% for the standard hybrid, when compared to yields under drought conditions.

The minimum criteria for QPM include TC of $0.075 \%$, PC of $0.8 \%$ and QI of $0.8 \%$ in whole grain samples, as well as modified endosperm (Twumasi-Afriyie et al., 2016). Overall, both ZPQPM6 and ZPQPM13 fulfilled criteria for protein and tryptophan contents. However, only ZPQPM13 was significantly better from the standard hybrid for all three traits analysed. Insignificant difference between ZPQPM6 and ZP606 is not surprising, since the lower limits of lysine and tryptophan in 0202 maize overlap with the upper limits in normal maize (Vivek et al., 2008). Quality index of ZPQPM13, although lower from the set threshold, can be regarded as acceptable. Hybrids with standard kernel quality had QI of 0.57$0.62 \%$ in Ignjatovic-Micic et al. (2013).ZPQPM13 had average QI of $0.70 \%$ in selfing field trials and $0.77 \%$ in mercantile production, which implies increased nutritional value of the QPM hybrid. Considering endosperm modifications, both QPM hybrids displayed overall high percentages of hard endosperm with average scores below 2, which corresponds to 
standard maize kernels (Vivek et al., 2008). Scores below 2 were also obtained in Pixley and Bjarnason (2002). However, presence of 5\%-6\% of soft endosperm kernels in ZPQPM6 and ZPQPM13 could have contributed to their lower yields when compared with standard hybrid ZP606.

All three quality traits showed variations in different years and on different locations. These variations were more pronounced for QPM hybrids, especially for TC and QI, which were much higher in 2017, a year in which drought stress occurred. Increased levels of TC under drought stress in QPM have already been recorded. In Zaidi et al. (2008) and Ngaboyisonga et al. (2012) this increase was found in CIMMYT tropical and subtropical genotypes, while in IgnjatovicMicic et al. (2015) it was detected in drought tolerant populations from MRIZP gene bank. Consequently, TC increase in adapted ZPQPM6 and ZPQPM13 could be attributed to the sub-tropical germplasm residues in their parental lines. Additionally, it was shown that tryptophan metabolism was enriched in maize drought-stressed kernels and that it plays a direct role in regulating plant development and defence responses in drought tolerant genotypes (Wang et al., 2019). This could also have had influence on TC increase in ZPQPM hybrids. On the other hand, different data on the PC under drought stress can be found in the literature. Protein content under drought stress was increased in Zaidi et al. (2008), Ngaboyisonga et al. (2012) and Ignjatovic-Micic et al. (2015) but decreased in Ali et al. (2010), which is in accordance with our results. These different responses in PC could be attributed to different levels of sensitivity of maize genotypes and drought severity, as adaptation to drought stress causes different alterations of protein expression in many metabolic pathways and cell functions, depending on the genotype and drought conditions (Yang et al., 2014).

Besides GY, another problem issued in QPM breeding and adaptation to temperate regions was stability of TC. Contrary to ZPQPM13, ZPQPM6 showed non-QPM values of tryptophan in the second year of the experiment. In Tandzi et al. (2017), it was emphasized that nutritional evaluation of QPM has proved the stability of lysine and tryptophan content within the prescribed range for QPM, despite quite diverse types of environmental conditions. Consequently, ZPQPM6 proved to be inadequate for the purposes of QPM utilization. For this reason, only ZPQPM13, which had high TC in both years and all locations in field trials, was identified as a hybrid with potential to be used in feed industry.

It is well known that lysine, tryptophan, methionine and threonine are critical for optimal broiler performance and the use of QPM in broiler feeds might remove the need to supplement broiler diets with the costly synthetic lysine (Mushipe et al., 2017). Moreover, it has been shown that QPM can increase the growth performance and feed efficiency, as well as carcass yield of broiler chicken (Panda et al., 2011; Mushipe et al., 2017; Rajasekhar et al., 2020). Biochemical analysis of mercantile kernel from ZPQPM13, produced in a small-scale mercantile production experiment, confirmed high lysine and tryptophan contents, as they are much higher than in maize with standard kernel quality, which typically has $0.29 \%$ to $0.33 \%$ lysine and $0.06 \%$ tryptophan (Scott et al., 2009). The usability of ZPQPM13 will be tested in broiler feeding trials.

\section{CONCLUSIONS}

The experiment presented in this paper showed that adaptation and cultivation of quality protein maize (QPM) hybrids in temperate regions is a hard task, most probably due to the presence of exotic tropical and sub-tropical germplasm. Nine out of 11 ZPQPM hybrids had low grain yield and poor agronomic performances and these lines must be further improved by backcrossing with adapted germplasm. Only ZPQPM13 expressed characteristics of a QPM genotype - good grain yield, high tryptophan and protein contents, good quality index, hard endosperm, and stability of tryptophan content in diverse environmental conditions. ZPQPM13 also had high lysine content of $0.44 \%$ and is a promising hybrid for use in broiler feeds, which could substitute costly synthetic lysine in their diets.

\section{ACKNOWLEDGEMENTS}

This research was supported by the Ministry of Education, Science and Technological Development of Republic of Serbia through the projects TR31028 and TR31068. 


\section{REFERENCES}

Agrawal, P.K., Mallikarjuna, M.G., and Gupta, H.S. 2018. Genetics and applied genomics of quality protein maize for food and nutritional security. p. 151-178. In Goasal, S.S., and Wani, S.H. (eds.) Biotechnologies of crop improvement. Volume 3. Genomic approaches. Springer, New York, USA.

Ali, Q., Ashraf, M., and Anwar, F. 2010. Seed composition and seed oil antioxidant activity of maize under water stress. Journal of the American Oil Chemists' Society 87:1179-1187.

HIDMET. 2017. Seasonal bulletin for Serbia Summer 2017. Climate Monitoring and Climate Forecasting Department. Hydrometeorological Institute Republic of Serbia (HIDMET), Belgrade, Serbia. Available at http://www.hidmet.gov.rs/ podaci/meteorologija/latin/12017.pdf (accessed September 2019).

HIDMET. 2019. Annual bulletin for Serbia 2018. Climate Monitoring and Climate Forecasting Department. Hydrometeorological Institute Republic of Serbia (HIDMET), Belgrade, Serbia. Available at http://www.hidmet.gov.rs/podaci/meteorologija/ latin/2018.pdf (accessed September 2019).

Ignjatovic-Micic, D., Kostadinovic, M., Stankovic, G., Markovic, K., Vancetovic, J., Bozinovic, S., et al. 2013. Biochemical and agronomic performance of quality protein maize hybrids adapted to temperate regions. Maydica 58:311-317.

Ignjatovic-Micic, D., Vancetovic, J., Trbovic, D., Dumanovic, Z., Kostadinovic, M., and Bozinovic, S. 2015. Grain nutrient composition of maize (Zea mays L.) drought-tolerant populations. Journal of Agricultural and Food Chemistry 63:1251-1260.

Kostadinovic, M., Ignjatovic-Micic, D., Vancetovic, J., Ristic, D., Bozinovic, S., Stankovic, G., et al. 2016. Development of high tryptophan maize near isogenic lines adapted to temperate regions through marker assisted selection - impediments and benefits. PLOS ONE 11(12):e0167635.

Krishna Motukuri, S.R. 2019. Quality protein maize: An alternative food to mitigate protein deficiency in developing countries. Intech Open, London UK. In Hossain, A. (ed.) Maize. Production and use. IntechOpen, London, UK. doi:10.5772/intechopen.89038.

Mertz, E., Bates, L., and Nelson Jr., O.E. 1964. Mutant gene that changes protein composition and increases lysine content of maize endosperm. Science 145:279-280.

Mi, N., Cai, F., Zhang, Y., Ji, R., Zhang, S., and Wang, Y. 2018. Differential responses of maize yield to drought at vegetative and reproductive stages. Plant, Soil and Environment 64:260-267.

Mpofu, I.D.T., Sibanda, S., Shonihwa, A., and Pixley, K.V. 2012. The nutritional value of quality protein maize for weaner pigs. Journal of Petroleum \& Environmental Biotechnology 3:1-5.

Mushipe, J., Kunaka, K., Masaka, J., and Chivandi, E. 2017. Effects of dietary substitution of ordinary maize meal with quality protein maize meal on the performance of broiler chicken. Asian Journal of Animal and Veterinary Advances 12:197-204.

Nabizadeh, E., Banifazel, M., and Taherifard, E. 2012. The effects of plant growth promoting on some of traits in maize (cv. S.C.704) under drought stress condition. European Journal of Experimental Biology 2:875-881.

Ngaboyisonga, C., Njoroge, K., Kirubi, D., and Githiri, S.M. 2012. Quality protein maize under low N and drought environments: endosperm modification, protein and tryptophan concentrations in grain. Agricultural Journal 7:327-338.

Panda, A.K., Raju, M.V.L.N., Rao, S.V., Lavanya, G., Reddy, E.P., and Sunder, G.S. 2011. Nutritional evaluation and utilisation of quality protein maize, Nityashree hybrid maize, and normal maize in broiler chickens. British Poultry Science 52:632-638.

Pixley, K.V., and Bjarnason, M.S. 2002. Stability of grain yield, endosperm modification, and protein quality of hybrid and open-pollinated quality protein maize (QPM) cultivars. Crop Science 42:1882-1890.

Rajasekhar, K.V., Prakash, B., Vijaya Lakshmi, K., Rama Rao, S.V., and Raju, M.V.L.N. 2020. Effect of feeding diet with alternate protein sources and quality protein maize on performance and nutrient utilization in broiler chickens. Tropical Animal Health and Production 52:2297-2302. https://doi.org/10.1007/s11250-020-02251-4.

Sah, R.P., Chakraborty, M., Prasad, K., Pandit, M., Tudu, V.K., Chakravarty, M.K., et al. 2020. Impact of water deficit stress in maize: Phenology and yield components. Scientific Reports 10:2944. https://doi.org/10.1038/s41598-020-59689-7.

Scott, M.P., Peterson, J.M., and Hallauer, A.R. 2009. Evaluation of combining ability of quality protein maize derived from U.S. public inbred lines. Maydica 54:449-456.

Sofi, P.A., Wani, A.S., Rather, A.G., and Wani, H.S. 2009. Quality protein maize (QPM): Genetic manipulation for the nutritional fortification of maize. Journal of Plant Breeding and Crop Science 1(6):244-253.

Tandzi, L.N., Mutengwa, C.S., Ngonkeu, E.L.M., Woïn, N., and Gracen, V. 2017. Breeding for quality protein maize (QPM) varieties: A review. Agronomy 7:80. doi:10.3390/agronomy7040080.

Thapa, G., Gautam, S., Bahadur Rahut, D., and Choudhary, D. 2020. Cost advantage of biofortified maize for the poultry feed industry and its implications for value chain actors in Nepal. Journal of International Food \& Agribusiness Marketing. doi:10.1080/08974438.2020.1780179.

Twumasi-Afriyie, S., Palacios-Rojas, N., Friesen, D., Teklewold, A., Wegary, D., De Groote, H., et al. 2016. Guidelines for the quality control of quality protein maize (QPM) seed and grain. CIMMYT, Addis Ababa, Ethiopia. 
Vivek, B.S., Krivanek, A.F., Palacios-Rojas, N., Twumasi-Afriyie, S., and Diallo, A.O. 2008. Breeding quality protein maize (QPM): protocols for developing QPM cultivars. CIMMYT, Mexico, D.F.

Wang, X., Zenda, T., Liu, S., Liu, G., Jin, H., Dai, L., et al. 2019. Comparative proteomics and physiological analyses reveal important maize filling-kernel drought-responsive genes and metabolic pathways. International Journal of Molecular Sciences 20(15):3743.

Worral, H.M., Scott, M.P., and Hallauer, A.R. 2015. Registration of temperate quality protein maize (QPM) lines BQPM9, BQPM10, BQPM11, BQPM12, BQPM13, BQPM14, BQPM15, BQPM16, and BQPM17. Journal of Plant Registrations 9:371-375.

Yang, L., Jiang, T., Fountain, J.C., Scully, B.T., Lee, R.D., Kemerait, R.C., et al. 2014. Protein profiles reveal diverse responsive signaling pathways in kernels of two maize inbred lines with contrasting drought sensitivity. International Journal of Molecular Sciences 15:18892-18918.

Zaidi, P.H., Vasal, S.K., Maniselvan, P., Jha, G.C., Mehrajjudin, and Singh, R.P. 2008. Stability in performance of quality protein maize under abiotic stress. Maydica 53:249-260.

Zarkadas, C.G., Hamilton, R.I., Yu, Z.R., Choi, V.K., Khanizadeh, S., Rose, N.G., et al. 2000. Assessment of the protein quality of 15 new northern adapted cultivars of quality protein maize using amino acid analysis. Journal of Agricultural and Food Chemistry 48:5351-5361. 